\title{
RECENT JUDICIAL DEVELOPMENTS OF INTEREST TO ENERGY LAWYERS
}

\author{
PATRICK W. BURGESS, WARREN P. FOLEY \\ AND BRADLEY D. MCFADDEN*
}

This article summarizes a number of recent judgments in the energy sector. These cases relate to a number of specific topics including receivership, employment, the duty to consult, freehold leases, contracts, and regulation. For each case, some background information is given, followed by a brief explanation of the facts, a summary of the decision, and some commentary on the decision.
Cet article résume un nombre de récentes décisions dans le secteur énergétique. Ces causes traitent de sujet précis incluant la mise sous séquestre, l'emploi, l'obligation de consulter, les baux francs, les contrats et la réglementation. Un contexte est donné pour chaque cause, suivi d'une brève explication des faits, un résumé de la décision ainsi que des observations sur la décision.

\section{TABLE OF CONTENTS}

I. RECEIVERSHIP . . . . . . . . . . . . . . . . . . . . . 402

A. KaSten ENERGY INC. V. SHAMROCK OIL \& GAS LTD. . . . . . . . . . 402

B. BAYTEX ENERGY LTD. V. MNP LTD. . . . . . . . . . . . . . . . . . . . . 403

II. EMPLOYMENT . . . . . . . . . . . . . . . . . . . . . . . 404

A. CEP, LOCAL 707 V. SUNCOR ENERGY INC. . . . . . . . . . . . 404

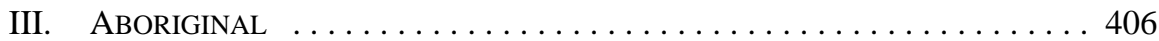

A. STONEY TRIBAL COUNCIL

V. IMPERIAL OIL RESOURCES LTD. . . . . . . . . . . . . . . . . . . . 406

B. MÉTIS NATION OF ALBERTA REGION 1

V. JOINT REVIEW PANEL . . . . . . . . . . . . . . . . . . . . 407

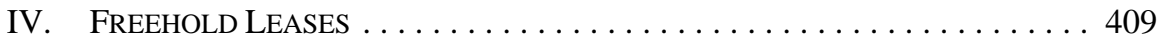

A. 1301905 ALBERTA LTD. V. SWORD ENERGY INC. . . . . . . . . . . . . 409

V. CONTRACT . . . . . . . . . . . . . . . . . . . . . 411

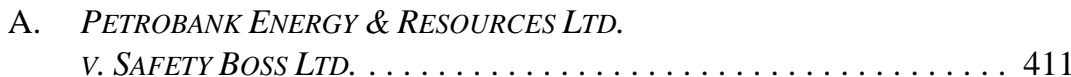

B. BELLATRIX EXPLORATIONS LTD.

V. PENn West Petroleum LtD. . . . . . . . . . . . . . . . . . . . . 414

C. NEXXTEP RESOURCES LTD. V. TALISMAN ENERGY INC. . . . . . . . . . 415

D. CANADIAN NATURAL RESOURCES LTD.

V. JENSEN RESOURCES LTD. . . . . . . . . . . . . . . . . . . . 418

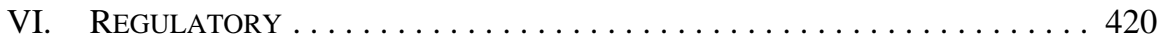

A. KELLY V. ALBERTA

(ENERGY RESOURCES CONSERVATION BOARD) . . . . . . . . . . 420

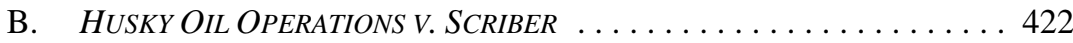

C. INTER PIPELINE FUND V.

ALBERTA (ENERGY RESOURCES CONSERVATION BOARD) . . . . . . . 424

Gowling Lafleur Henderson LLP. 


\section{RECEIVERSHIP}

\section{A. KASTEN ENERGY INC. V. SHAMROCK OIL \& GAS LTD. ${ }^{1}$}

1. BACKGROUND

This case deals with an application for the appointment of a receiver where the primary asset of the debtor is an oil and gas lease. In giving its decision, the Court comments on whether the complexity of oil and gas operations should influence receivership orders and on the utility of oil and gas leases in the context of bankruptcy proceedings.

\section{FACTS}

Shamrock Oil \& Gas Ltd. (Shamrock) is an oil and gas exploration company and the lessee of an oil and gas lease in the Swan Lake area of Alberta. In 2010 Shamrock entered into a contract with a predecessor company of Kasten Energy Inc. (Kasten) to construct a road to Shamrock's well site. The road was constructed and \$567,267.76 was incurred in construction costs. Shamrock and the predecessor company entered into a General Security Agreement (GSA) to secure repayment of the debt. ${ }^{2}$

Shamrock was unable to pay its creditors and in 2011 submitted a proposal (the Proposal) pursuant to section 50.4 of the Bankruptcy and Insolvency Act. ${ }^{3}$ The Proposal received Court approval in January 2012. In February 2012, Kasten issued a Notice of Intention to Enforce Security pursuant to section 244 of the BIA as the outstanding debt had grown to $\$ 760,059.18$ due to interest accruing and lack of payments on the part of Shamrock. By October 2012 Shamrock had only repaid $\$ 45,130.58$ of the total debt, and, as a result, Kasten brought an application seeking the appointment of a receiver over Shamrock's assets until the debt was repaid. ${ }^{4}$

\section{DECISION}

The Court granted Kasten's application determining that it was just and convenient that a receiver be appointed. It based its decision primarily on the fact that since the Proposal, Shamrock had taken virtually no steps towards repayment of the debt, and there were no steps short of appointing a receiver that were likely to result in repayment of the debt. The Court was not persuaded by Shamrock's argument that appointing a receiver would negatively impact oil and gas development which in turn would impact its ability to repay the debt. The Court stated: "[T]his concern is not insurmountable, given the broad management authority and discretion that a court appointed receiver would possess to enable it to do everything positively necessary to ensure that the operations of the relevant oil well continues in a productive and efficient manner."5

2013 ABQB 63, 76 Alta LR (5th) 407 [Kasten Energy].

Ibid at paras 4-6.

Bankruptcy and Insolvency Act, RSC 1985, c B-3 [BIA].

Kasten Energy, supra note 1 at paras 7-10.

Ibid at para 22. 
The Court also determined that the oil and gas lease held by Shamrock properly fell within the authority of a Court appointed receiver. Comparing the lease to a fishing license, it was noted that while the general security agreement did not apply to oil and gas substances under the ground, the lease granted the lessee the right to extract those substances and that right was transferable. ${ }^{6}$

\section{COMMENTARY}

This case confirms that the test for appointing a receiver in bankruptcy proceedings is whether it is just and convenient that the appointment be made. Even in the oil and gas industry, determining whether it is just and convenient to appoint a receiver is primarily determined by the debtor's ability to pay the outstanding debt. The uniqueness or complexity of an oil and gas operation is not a factor that should be given much weight as receivers have at their disposal the ability to hire highly skilled parties to ensure minimal interruption to the operation. The right to extract oil and gas substances is transferable, further adding to a receiver's ability to secure ongoing productivity to an oil and gas operation.

In making its decision, the Court held that oil and gas leases are a "proprietary interest within the purposive contemplation of Alberta's Personal Property Security Act."7 This aspect of the decision appears to conflict with the established law that an oil and gas lease is a profit à prendre. It is unclear whether Justice Lee intended to change the law as it relates to oil and gas leases or whether his decision is an outlier and restricted to the particular wording of the GSA in force between Shamrock and Kasten in the context of the receivership application.

\section{B. BAYTEX ENERGY LTD. V. MNP LTD. ${ }^{8}$}

1. BACKGROUND

In Baytex Energy the Court was required to assess the application of a Canadian Association of Petroleum Landmen (CAPL) Operating Procedure where one of the parties to the agreement incorporating the CAPL Operating Procedure was bankrupt.

\section{FACTS}

Baytex Energy Ltd. (Baytex) and Sterling Eagle Petroleum Corporation (Sterling) were partners in a number of wells in the Darwin area of Alberta. The governing agreements incorporated a version of the CAPL Operating Procedure. Baytex was the operator of the wells, and each party had a 50 percent interest in the producing wells. ${ }^{9}$

In 2011, Sterling was placed into receivership, and MNP was appointed as the receiver. In February 2012, Baytex, in its capacity as operator, sent a number of abandonment notices to Sterling and expressly indicated that failure to respond within 30 days would result in 
Sterling being deemed to have elected to take over the wells as proscribed by the abandonment procedure. MNP, as receiver, responded to Baytex's letters by advising them that the requests for abandonment were of no force and effect due to the Receivership Order. ${ }^{10}$ Baytex applied to have the abandonment notices enforced.

\section{DECISION}

The only issue in dispute in this matter was whether the Receivership Order prevented Baytex from relying on the provisions in the Operating Procedure to support the abandonment notices. The Court held that as the issuance of abandonment notices was done as a contractual right and not out of necessity, the abandonment notices were of no force and effect. The Court rejected Baytex's argument that the abandonment notices were issued in compliance with its duty as operator to ensure the wells complied with the applicable Energy Resources Conservation Board (ERCB) guidelines and regulations. Based on the materials provided by Baytex in the application, it was clear to the Court that the decision to abandon the wells was made for economic reasons. ${ }^{11}$

\section{COMMENTARY}

This case demonstrates the importance of involving the Court when dealing with partners whose assets are under the control of a receivership order. Ignoring a receivership order will typically result in wasted time and effort. Generally speaking, courts will support lifting the stay of proceedings of receivership to enable a non-bankrupt party to comply with mandatory legal requirements. In this case, the Court was not opposed to the notion of abandoning the wells, but opposed the application because the wells were abandoned for the sole purpose of passing future liability for the costs associated with the wells solely to a party that was in receivership.

\section{EMPLOYMENT}

\section{A. CEP, LOCAL 707 V. SUNCOR ENERGY INC.}

\section{BACKGROUND}

In CEP, Local 707 v. Suncor Energy Inc. ${ }^{12}$ and CEP, Local 707 v. Suncor Energy Inc. ${ }^{13}$ the Alberta Court of Appeal was required to consider an employer's right to institute mandatory drug testing policies in the context of injunction applications.

\section{2. $\quad$ FACTS}

Suncor proposed a policy that imposed drug and alcohol testing on its employees in safety sensitive jobs. Employees were to be selected on a random basis as chosen by a computer. Fifty percent of the workforce was to be tested annually, and the tests would require the 
provision of a urine sample. The policy was in response to a number of fatalities at Suncor locations believed to have resulted from drugs and alcohol. Suncor's existing drug testing policy only allowed for testing following an incident or when an individual appeared to be under the influence of drugs or alcohol. ${ }^{14}$

Following Suncor's attempted implementation of the policy, the union filed a grievance arguing that the policy did not comply with the collective agreement, was contrary to Canadian Charter of Rights and Freedoms, ${ }^{15}$ the Personal Information Protection Act, ${ }^{16}$ and the Human Rights Act. ${ }^{17}$ Suncor proceeded to enforce the policy pending the outcome of the grievance. In response, the union filed an injunction seeking to stay the policy until the grievance could be heard. The injunction was granted by the Alberta Court of Queen's Bench and Suncor made two applications to the Court of Appeal in relation to the injunction. ${ }^{18}$

\section{DECISION}

In October 2012, Suncor applied for a stay of the injunction until the appeal of the Court of Queen's Bench decision could be heard. This application was dismissed primarily on the basis that the time period between the application and the appeal was so brief that a stay of the injunction was not warranted. ${ }^{19}$

In November 2012, the Court of Appeal upheld the injunction obtained by the union. The Court of Appeal was satisfied that members of the union would suffer irreparable harm if the injunction was lifted because " $\mathrm{t}$ ] he non-consensual taking of bodily fluids is a substantial affront to an individual's privacy rights." ${ }^{20}$ The Court of Appeal further noted that there was no evidence that the policy would actually reduce accidents and that the policy was overly intrusive in that it was not limited to employees working in dangerous situations. Interestingly, in his dissenting decision, Justice Côté disagreed with the majority and noted that typically when courts find a policy overly broad, the solution is to limit the extent of the policy and not deny the application of the policy in any form. ${ }^{21}$

\section{COMMENTARY}

The union grievance was heard in December 2012, but it is unlikely that a decision will be given until the Supreme Court of Canada releases its decision in Irving Pulp \& Paper Ltd. v. CEP, Local $30 .^{22}$ Similar to the Suncor grievance, Irving is concerned with an employer's ability to institute random alcohol testing on employees working in safety-sensitive positions. It is clear from the Suncor cases that the decision by the Supreme Court of Canada will have to consider and balance many competing interests, including safety concerns and the

Ibid at paras 2-3.

Part I of the Constitution Act, 1982, being Schedule B to the Canada Act 1982 (UK), 1982, c 11.

SA 2003, c P-6.5.

RSA 2000, c A-25.5.

Suncor Energy No 1, supra note 12 at para 16.

Ibid at para 41.

Suncor Energy No 2, supra note 13 at para 5.

Ibid at paras 7-11, 23.

2011 NBCA 58, 375 NBR (2d) 92 [Irving]. 
employee's right to privacy. The Supreme Court of Canada heard the Irving appeal in December 2012 but a decision has not yet been released. ${ }^{23}$

\section{Aboriginal}

\section{A. Stoney Tribal Council V. Imperial OIL ReSOURCES LtD. ${ }^{24}$}

1. BACKGROUND

This case concerns the rights of beneficiaries in the context of Aboriginal law.

\section{FACTS}

The Stoney Tribal Council (Council) received certain rights to land through Treaty No. 7. ${ }^{25}$ Pursuant to the provisions of the Indian Oil and Gas $A c t^{26}$ and regulations issued thereunder, the Government of Canada (Canada) received royalty payments as trustee on behalf of the Council. Canada leased various lands to Imperial Oil Resources Ltd. (Imperial) and a dispute arose over the amount of the royalties being paid with respect to the subject lands. $^{27}$

On behalf of the Council, Canada initiated legal proceedings against Imperial, and the parties were able to resolve the disputes through settlement. The Council took exception to the terms of settlement primarily due to the fact that Imperial was never required to provide an accounting of the royalties owing. The Council initiated further legal proceedings against Imperial for the balance of what it said remained outstanding. Imperial applied to have the claim struck on the basis that (1) the Council had no standing; and (2) the issues in dispute had already been decided. ${ }^{28}$

\section{DECISION}

The Court agreed with Imperial and ruled that the Council had no standing to continue its claim against Imperial. ${ }^{29}$ The Court disagreed with the Council in ruling that there is a meaningful distinction between the Council's sui generis fiduciary relationship with the Crown and common law principles applying to trustees and beneficiaries. ${ }^{30}$ The Court

On 14 June 2013 the Supreme Court of Canada came out with its decision in the Irving appeal (see Communications, Energy and Paperworkers Union of Canada, Local 30 v Irving Pulp \& Paper, Ltd, 2013 SCC 34, 359 DLR (4th) 394). In a 6-3 decision the majority of the Supreme Court struck down Irving's random mandatory alcohol testing policy in safety sensitive areas. The Supreme Court held that (1) there was no evidence demonstrating that alcohol was a problem in safety sensitive areas; (2) mandatory random alcohol testing was an unjustified affront to the dignity and privacy of employees; (3) there was no evidence that changing the alcohol testing policy would increase the safety of employees in safety sensitive areas; and (4) the new policy was contrary to the provisions of the collective bargaining agreement.

2012 ABQB 557, 547 AR 369 [Stoney].

Ibid at para 3.

RSC 1985, c I-7.

Stoney, supra note 24 at paras 3-4.

Ibid at paras 5, 8-12, 20.

Ibid at para 73 .

Ibid at para 22. 
outlined the three prerequisites that must be met in order for a beneficiary to have standing to sue a third party debtor:

(1) the beneficiary must ask the trustee to bring the action and be refused;

(2) the beneficiary must also name the trustee as defendant if it sues a third party; and

(3) the beneficiary must exhaust its remedy against the trustee. ${ }^{31}$

The Court held that the Council failed to meet the prerequisites necessary for a beneficiary to sue a third party debtor and emphasized the fact that the Council failed to exhaust its remedies against its trustee, Canada. ${ }^{32}$

\section{COMMENTARY}

The Stoney decision confirms that in most cases the law of trusts has been held to apply to the fiduciary relationship that exists between Aboriginal people and the Crown. While the fiduciary relationship is sui generis, parties attempting to deviate from the law of trusts must lead evidence demonstrating why it is inappropriate to apply the relevant common law principles. Practically speaking, parties dealing with the Crown on the payment of royalties should be confident that those negotiations will not be subject to further scrutiny from an unsatisfied beneficiary (a Band Council) when the common law prerequisites for allowing a beneficiary to sue a third party debtor are not met.

\section{B. Métis Nation of Alberta Region 1 V. Joint ReView PANEL ${ }^{33}$ \\ 1. BACKGROUND}

This case deals with jurisdictional issues surrounding the Crown's duty to consult with Aboriginal people in relation to resource projects affecting claimed or recognized Aboriginal rights.

\section{FACTS}

Shell Canada (Shell), the operator of the Jackpine oil sands mine near Fort McMurray, applied for an amendment to its licence in order to expand the mine to include adjacent territory and to increase its capacity. ${ }^{34}$ In order to obtain the amendment, Shell required approval from the ERCB, the Alberta provincial regulator and the Canadian Environmental Assessment Agency (CEAA), a federal regulator. In order to avoid both a federal and a provincial regulatory review, the governments of Alberta and Canada entered into an agreement (the Agreement) in September of 2011 to create a joint review panel (the Joint 
Review Panel) ${ }^{35}$ under section 22(3) of the Energy Resources Conservation Act, ${ }^{36}$ and section 40 of the Canadian Environmental Assessment Act, 2012.37

The Agreement provided that the Joint Review Panel was to consider Aboriginal issues as part of its mandate, but specifically stated that the Joint Review Panel was not required to make any determination with respect to, inter alia, "whether the Crown has met its respective duties to consult or accommodate in respect of rights recognized and affirmed by section 35 of the Constitution Act, 1982.”38

As part of its proceedings, the Joint Review Panel invited interested parties to provide submissions in respect of constitutional issues they intended to raise. The Athabasca Chipewyan First Nation (the ACFN) and the Métis Nation filed submissions in respect of constitutional issues to be raised. Following a preliminary hearing to consider the scope of the constitutional issues to be considered in the main hearing, the Joint Review Panel issued a decision on 26 October 2012 declining to consider the constitutional issues raised by the ACFN and the Métis Nation. Among the several stated reasons that the Joint Review Panel provided for its refusal to consider these issues was that the Joint Review Panel "does not have an express grant of statutory authority to consider the adequacy of Crown consultation in relation to the Project. ${ }^{\text {’9 }}$ In contemplation of filing an appeal of the Joint Review Panel's decision, the ACFN and the Métis Nation applied to adjourn the hearing until their application for leave to appeal was heard. On 30 October 2012 the Joint Review Panel decided that the hearing would proceed notwithstanding the application for leave. ${ }^{40}$

\section{DECISION}

In dismissing the application for leave to appeal, the Court ruled that:

While the jurisdictional issues raised by the applicants are interesting in the abstract, it is not appropriate to grant leave to appeal as the answers to those questions would not affect the outcome of this hearing. The Joint Review Panel “... is not required ... to make any determination as to ... whether the Crown has met its respective duties to consult...”. The Joint Review Panel has clearly decided not to engage this issue, at least at this stage of its proceedings. It is entitled to do that. ${ }^{41}$

Of specific concern to the ACFN and the Métis Nation was their view that the Joint Review Panel hearing was the sole venue for Aboriginal issues to be considered and for the duty to consult to be met. In addressing this concern, the Court noted that in the event the expansion of the Jackpine mine proceeds without consultation, the ACFN and the Métis Nation could seek remedy from the Crown because the issuance of a permit would not serve to "extinguish the Crown's duty to consult."

Ibid at para 4.

RSA 2000, c E-10.

SC 2012, c 19.

Métis Nation, supra note 33 at paras 6-7 [emphasis omitted].

Ibid at para 9.

Ibid at paras 8-9.

Ibid at para 26 [emphasis in original].

Ibid at para 22. 


\section{COMMENTARY}

This case exemplifies the complexities which surround the Crown's duty to consult in relation to the development of resource projects and their impact on Aboriginal rights. The Joint Review Panel was created in an attempt to create an efficient regulatory process with respect to the application for the Jackpine expansion and to avoid a duplicative regulatory review at both the provincial and federal levels. Notwithstanding this intent, the Joint Review Panel lacks the authority to determine a critical issue that needs to be addressed in order for the Jackpine expansion to proceed; whether the Crown has discharged its duty to consult with Aboriginal peoples in respect of this project.

It appears that neither industry nor Aboriginal people have achieved a "win” with this decision. For industry, this decision makes clear that even if a full hearing is held, Aboriginal issues are heard and addressed, and a permit is issued, the Crown's duty to consult will remain an outstanding issue to be addressed. And until the Crown's duty to consult is satisfied, Shell will not be assured that the expansion can proceed as planned. For Aboriginal people, this decision could raise concern as to whether it is worth their time to appear at hearings like the one held by the Joint Review Panel, when the Court has made it clear that the Crown consultation to which they are entitled or the remedies they have for the failure to consult lie elsewhere.

Until the courts clarify what does and does not satisfy the Crown's duty to consult, any uncertainty surrounding what constitutes fulsome Crown consultation, and when such consultation should occur, will result in continued delays for proposed resource development projects that impact Aboriginal rights.

\section{FREEHOLD LEASES}

\section{A. 1301905 ALBERTA LTD. V. SWORD ENERGY INC. ${ }^{43}$}

\section{BACKGROUND}

This case reinforces the fact that a lessee must strictly comply with the provisions of the default clause of a freehold petroleum and natural gas lease, should a default notice be issued by the lessor, or else the lessee will risk losing its tenure under the lease and its right to defend against the alleged default.

\section{FACTS}

Sword Energy Inc. (Sword) was the successor in interest to the lessee in and to a petroleum and natural gas lease (the Lease) with Forrest Hagen covering 43-18-W4M: S1/2 of section 15 (the Lands). Pursuant to a lease assignment, 1301905 Alberta Ltd. (1301905 Alberta) was the successor in interest to the lessor's interest in the Lease. ${ }^{44}$ 
On 26 January 2010, 1301905 Alberta sent a default notice to Sword (the Default Notice) pursuant to Clause 15 of the Lease (the Default Clause), alleging that Sword was in breach of Clause 8 of the Lease (the Offset Well Clause) and claiming that 1301905 Alberta was accordingly entitled to payment of a compensatory royalty from Sword. ${ }^{45}$ The Judge quoted the following portion of the Default Clause, which follows the standard default clause in the CAPL 91 form of lease:

(a) If, before or after the expiry of the primary term, the Lessor considers that the Lessee has not complied with any provision or obligation of this Lease ... the Lessor shall notify the Lessee in writing, describing in reasonable detail the alleged breach or breaches. The Lessee shall have 30 days after receipt of such notice to:

i) remedy or commence to remedy the breach or breaches alleged by the Lessor, and thereafter diligently continue to remedy the same; or

ii) commence and diligently pursue proceedings for a judicial determination as to whether the alleged acts or ommisions [sic] constitute a breach or breaches on the part of the Lessee. ${ }^{46}$

Sword replied to the Default Notice by way of a letter dated 24 February 2010 (the Sword Reply) wherein it stated its opinion that there had been no breach of either the Default Clause or the Offset Well Clause and, as such, Sword was not required to commence proceedings for a judicial determination of whether the alleged act or omission constituted a breach. Sword neither paid the requested compensatory royalties under the terms of the Offset Well Clause to 1301905 Alberta, nor did it commence proceedings within 30 days of receipt of the Default Notice in accordance with the provisions of the Default Clause. Sword did, however, provide notice to 1301905 Alberta on 22 June 2011 that it was terminating the Lease and surrendered the offset zones in the well drilled on the Lands. ${ }^{47}$

1301905 Alberta made an application for summary judgment for the alleged breaches of both the Default Clause and the Offset Well Clause. While Sword acknowledged it had breached the Default Clause by failing to commence judicial proceedings with respect to the alleged breach of the Offset Well Clause within 30 days of receipt of the Default Notice, it objected to the summary judgment application on the basis that there was an outstanding question as to whether or not it had breached the Offset Well Clause. ${ }^{48}$

\section{DECISION}

In granting the application for summary judgment, the Court found that the Default Clause's 30 day time period to commence judicial proceedings upon receipt of the Default Notice served as a limitation period, and Sword's failure to commence such proceedings resulted in its right to defend its position that there was no breach of the Offset Well Clause being “extinguished or cancelled.”49

Ibid at para 8.

Ibid at para 7

Ibid at paras 8-10.

Ibid at paras 14, 18-19.

Ibid at paras 37, 41. 
The Court added that Sword was aware of its obligations to commence such judicial proceedings if it disputed the alleged breaches outlined in the Default Notice and that Sword's unilateral determination that there was no breach, as was stated in the Sword Reply, was not sufficient to comply with those obligations. ${ }^{50}$

As a result of the Court's analysis, the Court ruled that:

Sword is legally presumed to be in breach of the Offset Well[s] Clause in the Lease based on its failure to commence proceedings for judicial determination of (i.e. challenge to) the alleged breach of the Offset Well[s] Clause within 30 days after Sword's receipt of the Default Notice from the Applicant. And consequently, the Applicant Lessor becomes entitled to its remedy for damages in the context of the terms of the entire Lease, including Clause $15(\mathrm{c}) .^{51}$

\section{COMMENTARY}

The first response of many lessees of petroleum and natural gas leases who receive default notices in respect of an alleged breach that they disagree with is to respond in the same manner as Sword did (that is, dispute the validity of the alleged breach via letter to the lessor). Lessees should be wary of this approach or of thinking they can simply negotiate out of the default notice, particularly if a CAPL form lease is involved, because Sword shows us that failing to commence judicial proceedings to determine if the alleged breach is in fact a breach will result in the lessee being presumed to be in breach.

While companies may find it onerous and inefficient to have to commence proceedings every time they receive a default notice they disagree with, the fact that $S$ word resulted in the grant of summary judgment shows the serious consequences of failing to strictly comply with the terms of the default provisions of the lease. While contrary to the common goal of oil and gas companies to resolve potential disputes outside of the courtroom and in a negotiated manner, lessees are advised to commence their judicial proceedings within the required time frame after receipt of each and every default notice they object to.

\section{CONTRACT}

\section{A. PETRobank ENERGy \& ResourCes LtD. V. SAFEty Boss LtD. ${ }^{52}$ \\ 1. BACKGROUND}

This case deals with breaches of contract and negligence in the context of an emergency environmental situation. Of particular interest is the fact that there was no written agreement between the parties. 


\section{FACTS}

Petrobank Energy \& Resources Ltd. (Petrobank) was the owner of a well located at 5-31116-10 W6M (the Well). The Well was suspended for economic reasons and had been acquired by Petrobank from a party not involved in this dispute who was undergoing financial difficulty. ${ }^{53}$

On 11 June 2001, a blowout occurred at the Well which required immediate action. Later that evening Petrobank met with Safety Boss Ltd. (Safety Boss) to discuss responding to the blowout. By 12 June, Safety Boss had begun to take steps to control the Well on behalf of Petrobank and subsequently issued a Special Service Work Order (the Work Order) which set out a number of terms and conditions in relation to payment and the services provided. ${ }^{54}$

Petrobank was unhappy with the work, the invoice amounts, and the invoice practices of Safety Boss. On 29 June, the Safety Boss arrangement was terminated and the job of controlling the Well was given to a third party company. In total Petrobank spent $\$ 24,000,000$ to control the Well and remediate the environmental damage. Petrobank sued Safety Boss in the amounts of $\$ 3,200,878$ for excessive invoice costs and $\$ 6,419,619$ for increased environmental damage resulting from unnecessary delay. ${ }^{55}$

\section{DECISION}

The Court awarded Petrobank \$753,552 for excessive invoice costs and \$855,949 for environmental cleanup charges on the basis of breach of contract and negligence. The primary areas of dispute were the terms of the contract and the resulting duty of care owed by Safety Boss. The decision-making process was complicated by the facts that many of the witnesses lacked credibility and the subject matter of the lawsuit required extensive expert opinion. $^{56}$

The Court drew the following conclusions:

(1) Formation of the Contract: The Court ruled that a contract was formed during the initial meeting held on the evening of 11 June 2001 and rejected Safety Boss' argument that no contract was formed until the Work Order was signed by Petrobank on 14 June 2001. The Court based its decision on the fact that the understanding of the parties as of 11 June 2001 was that Safety Boss was hired to take whatever steps were necessary to control the Well. This is an important aspect of this decision because the Work Order contained an exclusion of liability provision which was not part of the 11 June 2001 contract. $^{57}$

(2) Contract Fees: The Court rejected Petrobank's argument that the terms of the agreement required Safety Boss to only include reasonable charges. In the 
circumstances, Petrobank did not have the luxury of bargain shopping for competitive prices and understood that Safety Boss' services would be expensive. However, the Court did not allow Safety Boss to charge rates that exceeded its internally prepared price list as of the date of the blowout of the Well. ${ }^{58}$

(3) Timing of the Contract: The Court held that the nature of the services provided justified implying that time was of the essence in respect of the services provided by Safety Boss. ${ }^{59}$

(4) Payment Terms: As there was no discussion of payment terms at the initial meeting, the Court held that payment was due in accordance with the invoices issued by Safety Boss which stipulated that invoices were to be paid within 30 days. ${ }^{60}$

(5) Exclusion Provision: The Court did not allow Safety Boss to rely on the exclusion provision that formed part of the Work Order. The initial meeting on 11 June 2001 gave rise to the contract between the parties and there was no discussion of the exclusion provision until several days later and after work on the Well had commenced. ${ }^{61}$

Based on the Court's findings on the contract and based on the services provided by Safety Boss, the Court held that Safety Boss had owed a duty of care to Petrobank. Moreover, it held that Safety Boss breached its duty of care by failing to provide meaningful or helpful recommendations. In the Court's view, Safety Boss was the expert with extensive experience in the area of well remediation. While Petrobank was responsible for making decisions on recommendations made by Safety Boss, Petrobank was not expected to come up with solutions for the problems Safety Boss was hired to resolve. ${ }^{62}$

In the end, the Court's conclusion on damages related to excessive delay. Safety Boss' breaches of contract and negligence resulted in the remediation process taking two days longer than it should have. This resulted in excessive costs and increased environmental damage for which Petrobank was entitled to seek recovery from Safety Boss. ${ }^{63}$

\section{COMMENTARY}

While this case is expert driven and fact specific it serves as a reminder of the importance of clarity when negotiating business arrangements. Even in emergency type situations, discussions of contractual expectations will go a long way to avoid potential complications and related expenses. This case also provides an important reminder of the role that context plays when courts are required to interpret contractual relationships, especially in instances where the agreement in question is oral. 
B. Bellatrix explorations Ltd. V. Penn West Petroleum Ltd. ${ }^{64}$

\section{BACKGROUND}

This case is concerned with the nature of without prejudice settlement discussions including the impact, if any, that such discussions might have on the application of the Limitations Act. ${ }^{65}$

\section{2. $\quad$ FACTS}

Penn West Petroleum Ltd. (Penn West) operates a gas processing plant. Bellatrix Explorations Ltd. (Bellatrix), and its predecessor in interest, had been using the gas plant since at least 2007. In June 2007, Penn West advised Bellatrix’s predecessor that corrections were required to previous production numbers from the gas plant. By March 2009 corrections had not been made and Bellatrix contacted Penn West in an effort to expedite delivery of the corrections. The parties exchanged without prejudice communications in an effort to resolve their dispute. Ultimately, the parties could not resolve the dispute amicably and litigation was commenced. ${ }^{66}$

In the context of the litigation, a dispute arose over the admissibility of the without prejudice communications that were exchanged between 21 May 2009 and 7 August 2009. The Master ruled that the communications were privileged, but that the interest of justice allowed an exception to the admissibility of privileged information for the limited purpose of allowing Bellatrix to respond to the limitations defence. On appeal, the Master's decision was supported by the Court of Queen's Bench Judge. The parties appealed the Court's decision on the admissibility of the "without prejudice" communications. Bellatrix argued that the communications were not privileged and Penn West argued that an exception to settlement privilege was not met in this case. ${ }^{67}$

\section{DECISION}

The Court of Appeal ruled that all communications exchanged after 22 June 2009 fell within the scope of settlement privilege and that this privilege should not be waived to allow Bellatrix to answer the limitations defence. The communications exchanged between 27 May 2009 and 22 June 2009, however, were merely examples of the parties stating their positions and as those communications did not exhibit any compromise they cannot be protected by settlement privilege. The Court noted that because Penn West did not provide Bellatrix with the data that would have allowed Bellatrix to assess its position until after 22 June 2009, no true compromise could have been made by either party. ${ }^{68}$

The Court of Appeal overturned the lower court decisions on the waiver of privilege on the basis that privilege is of such importance it may only be waived in exceptional

2013 ABCA 10, 542 AR 83 [Bellatrix Exploration].

RSA 2000, c L-12.

Bellatrix Exploration, supra note 64 at paras 2-12.

Ibid at paras 13-19.

Ibid at paras 35-37. 
circumstances. The parties in this dispute were sophisticated parties who could have utilized tolling or standstill agreements to preserve limitation rights. As such, the Court ruled that there was nothing exceptional in these circumstances that would warrant waiving privilege. ${ }^{69}$

\section{COMMENTARY}

This case is an important reminder that settlement privilege is determined by the content and not the form of the subject communication. The key ingredient necessary to enforce settlement privilege is compromise. To fall under the protection of settlement privilege, the communication must exhibit genuine compromise of a party's position.

\section{NEXXTEP RESOURCES LTD. V. TALISMAN ENERGY INC. ${ }^{70}$}

\section{BACKGROUND}

The land schedules that describe the lands, zones, and hydrocarbon rights being acquired pursuant to a purchase and sale agreement typically form the basis of the overall asset package being acquired. Often, these land schedules are generated from the vendor's land records system and, depending on the size of the transaction and the customary practice of the vendor, they may or may not be verified to ensure an accurate description of the rights intended to be sold.

This case deals with the ability of a court to consider the "factual matrix" when interpreting a contract.

\section{FACTS}

Nexxtep Resources Ltd. (Nexxtep) and Talisman Energy Inc. (Talisman) entered into a letter agreement dated 1 May 2003 (the 1st Letter Agreement) in respect of the acquisition by Nexxtep of certain oil and gas assets in the Leedale area. The sale included Talisman's interest in Section 16, described as (1) a 72.4763 percent working interest from base of Cardium to base of Mannville (the Shallow Rights), including a producing vertical gas well (the Sweet Gas Well); and (2) a 34.4263 percent non-operated working interest after payout from base of Mannville to base of Pekisko (the Deep Rights), which contained a producing horizontal well (the Calpine Well).

The parties did not complete the transaction contemplated in the 1st Letter Agreement, but instead entered into another letter agreement, dated 15 December 2003 (the 2nd Letter Agreement). Closing did not occur in respect of the 2nd Letter Agreement, and, as a result, Nexxtep filed a statement of claim (the Claim) seeking the interests set out in the 2nd Letter Agreement.

Notwithstanding the Claim, the parties continued negotiating and eventually entered into a purchase and sale agreement dated 31 March 2004 (the PSA). Schedule "A” to the PSA 
listed, inter alia, the Deep Rights, which were the only interests to be acquired by Nexxtep in Section 16. The PSA did not include the Shallow Rights or the Sweet Gas Well in the assets to be acquired by Nexxtep.

Two years after the closing of the transaction governed by the PSA was completed, Nexxtep discovered that the production obtained from the Sweet Gas Well was from a pool within the Deep Rights. Nexxtep applied for, and the ERCB granted, the re-designation of the pool as being from below the base of the Mannville pool. Nexxtep then sued Talisman for trespass and conversion.

In denying Nexxtep’s claim for trespass and conversion, the trial Court found that the:

\begin{abstract}
result [as proposed by Nexxtep] is contrary to the intention of the parties as manifested in the PSA read as a whole within its proper factual matrix. Nexxtep hangs everything on six words ("PNG base Mannville to base Pekisko") in one box of the land schedule; it ignores the other parts of the PSA that show an intention to convey tangibles and miscellaneous interests along with petroleum and natural gas rights, and the evidence that leads through two letter agreements and a statement of claim expressly referred to in the PSA. A reasonable person looking at the entire PSA and the factual matrix would conclude that the intended subject of conveyance with respect to Section 16 rights was Talisman's entire $34.4263 \%$ working interest in the petroleum and natural gas rights below the base of the Mannville zone, but excluding the pool from which the vertical well produced. The words they used meant exactly that on March 31, 2004. ${ }^{71}$
\end{abstract}

Nexxtep appealed the trial Court's ruling on the basis that the decision failed to properly apply the law regarding contractual interpretation.

\title{
3. DECISION
}

A court's interpretation of a contract is not confined to examining only the words used and the common understanding of those words. Contextual evidence of the surrounding circumstances, including facts known to the parties at the time the contract was made, is part of the interpretative process. ${ }^{72}$

The Court undertook an analysis of Schedule "A" of the PSA and noted that only the 34.4262 percent working interest in the Deep Rights was listed, with no reference to the Shallow Rights (from which the parties believed, at the time, the Sweet Gas Well was producing). The Court also noted that Schedule "C" identified the Calpine Well producing from the Wilson Creek as comprising part of the "Assets.” The Court thought Schedules "A" and " $\mathrm{C}$, when read together, made it unclear as to what Nexxtep purchased. As a result, the Court said it was necessary to examine other parts of the PSA to "ascertain the intention of the parties."73

The Court referenced Talisman's condition precedent in the PSA that Nexxtep execute a release and quit claim relating to the 1st Letter Agreement, the 2nd Letter Agreement, and 
the Claim. ${ }^{74}$ The Court found that the "entire agreement" clause did not prevent the consideration of these outside agreements because they were specifically referred to in the PSA and their consideration was only for the purpose of interpreting and understanding the intention of the parties with respect to the PSA.

Finally, the Court ruled that it was appropriate for the trial Court to admit expert and regulatory evidence indicating that it would be difficult and unpredictable for a purchaser of a pool to obtain a license to produce it without also having purchased the well and production facilities. Such evidence served to assist in constructing the factual matrix surrounding the commercial context of the PSA. ${ }^{75}$

The Court concluded that an objective interpretation of the PSA, when examined as a whole and within the factual matrix, demonstrated that the Section 16 asset sold was only the 34.4262 percent working interest below the base of the Mannville zone, with "base of Mannville to base Pekisko" being a reference to the space within which production was being obtained from the Calpine Well. ${ }^{76}$ The facts known to the parties at the time of making the PSA did not include the Sweet Gas Well being produced from within the Deep Rights and it is clear that the descriptions used in the PSA referred only to Talisman's interest in the Calpine Well. ${ }^{77}$

\section{COMMENTARY}

The Court's decision relied heavily on using the wells and related tangibles acquired by Nexxtep as a means of determining the nature of the hydrocarbon interests acquired by Nexxtep. This seems contrary to standard industry practice where the genesis of the "Assets" is the described petroleum and natural gas rights (and any zonal restrictions), while the wells and tangibles included are merely those tied to the petroleum and natural gas rights.

The Court's decision seems focused on the fact that Nexxtep did not buy the Sweet Gas Well and therefore could not claim any production therefrom, even if that production came from the zones and formations clearly bought by Nexxtep. This raises the potential risk that parties may no longer be able to rely on the land schedule as the definitive basis of zones and substances they acquire. Such a risk could require purchasers to review every well in the vicinity of the rights to be acquired to confirm whether or not these may be completed to a zone of interest, in order to ensure that their acquired reserves are not subsequently drained from another party on the basis of a "past mistake.” It is also interesting to note that neither party plead mutual mistake in the case. 


\section{CANAdian NATURAL RESOURCES LTD. V. JENSEN RESOURCES LTD. ${ }^{78}$}

\section{BACKGROUND}

This case deals with issues that arise under private contract when the government exercises it regulatory rights to cause a material change to the terms of the contract.

\section{2. $\quad$ FACTS}

Canadian Natural Resources Ltd. (CNRL) was the successor in interest to the working interest in and to the petroleum natural gas rights in 55-4-W4M: sections 1, 4 and 32 (the Lands). These rights were originally granted pursuant to certain Alberta Crown Petroleum and Natural Gas Leases (the Original Leases), which were issued between 1975 (with respect to sections 1 and 4) and 1976 (with respect to section 32). Jensen was the successor in interest to certain royalty interests in these lands, which interests had been granted by the original holder. The royalty agreements granting and governing these interests, entered into in 1978 and 1980 (the Royalty Agreements), each provided: "The GROSS OVERRIDING ROYALTY interest herein conveyed shall attach to and encumber the Petroleum and Natural Gas Lease above described, and any renewals or extensions thereof, or any new leases which may be executed in lieu thereof, subject to the terms of this agreement."

Pursuant to Oil Sands Order 3, issued by the ERCB on 7 August 1984, the strata designated as the Mannville Group in an area which included the Lands became part of the “Cold Lake Oil Sands Area.” This resulted in the Original Leases ceasing to apply to petroleum rights in the Mannville zone underlying the Lands. Upon application by CNRL's predecessor in interest, the Government of Alberta subsequently issued "Oil Sands Leases" in respect of those the rights in the Mannville zone formerly held by the Original Leases and production was subsequently obtained.

In November of 2007, it was brought to Jensen's attention that CNRL was only paying royalties in respect of production from section 32, but not in respect of production from sections 1 and 4. After raising the issue of non-payment, CNRL took the position that no royalties were payable in respect of any of the Lands because the rights in question were no longer governed by the Original Leases and the Oil Sands Leases were not issued "in lieu thereof.” Jensen disagreed with this interpretation. The issue was whether Jensen's royalty interest which applied to the Original Leases carried over to the Oil Sands Leases.

\section{DECISION}

Parties are generally held to have contracted with reference to the law as it existed at the time of the contract, unless the parties properly manifest their intention to bind themselves to any future state of the law. ${ }^{80}$ With this in mind, the Court noted that at the time the Royalty Agreements were entered into (in 1978 and 1980), section 116 of the Mines and Minerals 
Act stated: "A petroleum and natural lease grants the rights to the petroleum and natural gas that are the property of the Crown in the location subject to any exceptions in the lease." ${ }^{\prime}$

As such, at the time the Royalty Agreements were executed, Jensen would have been entitled to a royalty on all petroleum produced from the Mannville zone. ${ }^{82}$ The Court further noted that at such time, the petroleum rights would not have been considered "oil sands" under the definition provided in section 2(1)(20) of the Mines and Minerals Act. ${ }^{83}$

It was not until the passage of the Oil Sands Conservation Act ${ }^{84}$ in 1983 that the definition of "oil sands" was amended to include "a hydrocarbon substance declared to be oil sands in section 7(2) of the Oil Sands Conservation Act." 85 The Court looked at the process that CNRL's predecessor in interest took to obtain oil sands leases in replacement of the Original Leases $^{86}$ and concluded that the Royalty Agreements applied to the Oil Sands Leases. ${ }^{87}$ The Court ruled that the Oil Sands Area Order 3 had served to declare all petroleum in the Mannville zone underlying the Lands to be "oil sands" and removed them from the Original Leases. The holders of the Oil Sands Leases participated in the application process for the Oil Sands Leases to be issued in respect of the Lands and which were ultimately awarded. The Court was satisfied that the combined result of these actions was that the Oil Sands Leases were issued in place of the Original Leases and, as such, the Royalty Agreements continued to govern. ${ }^{88}$

\section{COMMENTARY}

This case shows that the terms used in agreements dealing with interests in lands must be properly drafted in order to protect the rights and value provided therein from future (and unexpected) changes to the regulatory landscape. As was confirmed by the Supreme Court of Canada in Bank of Montreal v. Dynex Petroleum Ltd., ${ }^{89}$ a royalty interest can be an interest in land if:

(1) the language used in describing the interest is sufficiently precise to show that the parties intended the royalty to be a grant of an interest in land, rather than a contractual right to a portion of the oil and gas substances recovered from the land; and

(2) the interest, out of which the royalty is carved, is itself an interest in land. ${ }^{90}$

Query whether this dispute would have proceeded to trial if the Royalty Agreements contained "sufficiently precise" language to describe the royalty interests granted therein as an interest in land, as opposed to tieing the interests to the Original Leases. If we view the rights granted by the Royalty Agreements as interests in land (and assume that the granting

RSA 1970, с 238.

Ibid; supra note 78 at para 35.

Ibid.

Oil Sands Conservation Act, SA 1983, c O-5.5.

Ibid; supra note 78 at para 38.

Ibid at paras $42-46$.

Ibid at para 54.

Ibid at para 55.

Bank of Montreal v Dynex Petroleum Ltd, 2002 SCC 7, [2002] 1 SCR 146 [Dynex]. Ibid at para 22. 
language therein satisfies the test set out in Dynex), it would seem clear that such interests would have applied to all petroleum and natural gas rights granted by the Original Leases, and the reclassification of certain substances as "oil sands" and their apparent severance from the Original Leases would not have served to extinguish the royalty interest (assuming that the rights remain subject to a subsequent lease held by the same party, as was the case in this matter).

\section{REGULATORY}

\section{A. Kelly V. Alberta (ENERgy Resources Conservation BoARd) ${ }^{91}$}

\section{BACKGROUND}

The ERCB is the provincial regulator of natural resource development in Alberta and its primary mandate is to ensure the orderly and efficient development of Alberta's natural resources.

Pursuant to section 26(2) of the Energy Resources Conservation Act, ${ }^{92}$ the ERCB can provide notice to persons whose rights may be directly or adversely affected by a decision of the ERCB in respect of an application for natural resource development. Those persons who qualify as intervenors may be granted standing by the ERCB and participate in the resultant hearings. Section 28(2) of the Act also gives the ERCB discretion to make an award of costs to those who qualify as "local intervenors," in order to compensate them for the costs incurred by such participation.

This case deals with the issue of whether "local intervenors" are entitled to an award of costs.

\section{2. $\quad$ FACTS}

The appellants were the owners of lands in the vicinity of wells drilled and operated by Grizzly Resources Ltd. (Grizzly). At the time of Grizzly's application for these well licenses, the appellants applied for and were denied intervenor status under section 26 of the Act. The ERCB denied standing on the basis that they were not "directly and adversely affected."93 That decision was appealed to the Alberta Court of Appeal, who directed that the ERCB conduct a rehearing of the well license application.

By the time the ERCB conducted the rehearing, Grizzly had already drilled the wells, so the hearing was focused on whether Grizzly should be allowed to operate those wells. The ERCB decided that the appellants had not demonstrated any risk to themselves from the wells, that the emergency response procedures in place were satisfactory, and that the wells could be operated without any additional conditions. ${ }^{94}$ 
The appellants subsequently applied to the ERCB for an award of costs, but the ERCB denied the application on the basis that the appellants were not "local intervenors" under section 28(1) of the Act because they failed to show that the subject operations would "directly and adversely" affect the lands which they owned and occupied. The ERCB noted, in particular, that instead of showing an impact on such lands, the appellants instead raised concerns relating to their health and safety. ${ }^{95}$

The appellants appealed this decision to the Alberta Court of Appeal. The main issues on appeal related to the interpretation of section 28(1) of the Act and whether:

(1) the detriment or potential detriment must only be to the soil or improvements on the land or can the detriment include interference with occupation, use or enjoyment of the land by people, plants, animals, or chattels (including danger to health); and

(2) the relevant facts for that subjection are tested or fixed at the time the proceedings began, or during the proceedings, or only at the time of the costs application after the Board's substantive decision. ${ }^{96}$

\section{DECISION}

a. Can the Detriment Be to Occupation, Use, or Enjoyment of Land (Including Danger to Health)?

The Court ruled that it was unreasonable for the ERCB to limit section 28 of the Act only to instances of physical damage to land itself. It ruled that in context "land" must include the value and use of the land. ${ }^{97}$ Since the general purpose of the regulatory process conducted by the ERCB is to assist in preventing or reducing the likelihood of physical damage to lands, such a narrow interpretation would have resulted in section 28 being applied only in situations where the proposed resource development was likely to cause physical damage to land. At most hearings, it is likely that off-site physical damage as a result of natural resource development is not contemplated, therefore, it is not reasonable to assume that the Act is only intended for such narrow circumstances.

\section{b. At What Time Are the Relevant Facts Tested or Fixed?}

The Court noted that the ERCB's decision to deny the award of costs to the appellants emphasized the results of the hearing and that this results oriented approach resulted in the success (or lack thereof) in the intervention as being likely determinative of the issue. ${ }^{98}$

The Court noted that the regulatory process is not like civil litigation, where costs generally go to the victorious party. Instead of being a strictly adversarial process, like civil litigation, regulatory hearings are focused on the public interest. In that sense, all 
interventions that raise legitimate concerns are "successful” because that means that public input was obtained in respect of the natural resource development process. ${ }^{99}$

\section{c. Awarding of Costs}

The Court also looked at sections 26 and 28 of the Act, both of which reference development which "may" cause adverse effect. Allowing "success" to be the determining factor in the award of costs is inconsistent with the use of the word "may" in the Act. While it is up to the ERCB to conduct a substantive hearing in order to determine whether the evidence presented shows that there is an adverse affect, for the purposes of an award of costs, it is sufficient if, at the beginning of the process, it is reasonable to believe that the evidence "may" disclose an adverse effect.

Finally, the Court addressed the public policy effect of the ERCB's decision, noting that “the Board may well be 'thwarted' in discharging its mandate if the policy on costs is applied too strictly."100

The Court stated that the granting of standing and holding hearings is an important part of the natural resource development process, and this process can only be effective if it is open, inclusive and accessible. The Court noted that the reality, however, is that the costs of intervening and being a part of this process can be expensive for ordinary Albertans. Awarding costs is often necessary to facilitate or encourage public participation and to allow the ERCB to discharge its public mandate and provide a forum for the people to be heard. As a result, the Court ruled that it is not unreasonable for resource companies to bear the costs of intervenors because it is the resource companies that will obtain the reward of natural resource development. ${ }^{101}$

\section{COMMENTARY}

This case reinforces the importance of public participation in the regulatory process. As such, energy companies should be aware that they may be responsible for the costs of all local intervenors that raise legitimate concerns with respect to resource development, even if those concerns relate to health, safety, or the use of lands.

\section{B. HUSKY OIL OPERATIONS V. SCRIBER ${ }^{102}$}

\section{BACKGROUND}

Pursuant to the Surface Rights Act of Alberta, ${ }^{103}$ the Surface Rights Board of Alberta (SRB) is the regulatory body charged with settling surface access issues between surface land owners and natural resource companies.

\footnotetext{
$99 \quad$ Ibid at para 31.

$100 \quad$ Ibid at para 34

101 Ibid.

1022013 ABQB 74, 225 ACWS (3d) 1141 [Husky Oil].
}

103 RSA 2000, с S-24. 
This case deals with the calculation of "loss of use" and whether the SRB needs to take into account the out of pocket costs that are not spent by a land owner as a result of the lands being used for resource development, instead of agriculture.

\section{FACTS}

Scriber Farm (Scriber) holds 7,500 acres of land northwest of Lloydminster, Alberta, comprised of 5,000 acres used for grain production and 2,500 acres for pasture. Some (19.065) of this land is under lease to Husky Oil Operations (Husky) for well sites under right of entry orders granted by the SRB between 30 October 2009 and 25 February 2010 (the Entry Orders). ${ }^{104}$

In the Entry Orders, the SRB set the compensation to Scriber for Loss of Use at $\$ 480$ per acre. This was based on a three year pricing average of $\$ 535$ per acre, discounted by 10 percent. The $\$ 480$ per acre number arrived at by the SRB was $\$ 180$ per acre higher than what Husky had negotiated with other local farmers and was justified by the SRB on the basis of the significantly higher yields produced by Scriber. Scriber acknowledged that the direct costs to produce their yield were approximately \$185 per acre. Husky argued that these direct costs should be deducted from the "loss of compensation" figure, in order to provide a net "loss of compensation" sum of $\$ 295 .{ }^{105}$ As the Court put it, the issue is whether the SRB should have made its award based on gross margin rather than a gross revenue basis. ${ }^{106}$

\section{DECISION}

The Court noted that if direct input costs were deducted from Scriber's compensation, they would receive less money for "loss of use" than the surrounding land owners with whom Husky had negotiated arrangements (\$295 versus \$300), even though Scriber produced a significantly higher yield than those surrounding farms. ${ }^{107}$

The Court also noted that to require the SRB to require a deduction of input costs would "lead to operators peering into otherwise private documents and records and potentially interfering in farming practices by questioning such things as whether farmers have mitigated losses by economies that might make sense to an operator but not a landowner.”108

The Court then ruled that the idea of deducting direct costs in calculating "loss of use" is inconsistent with the Act because it would complicate the process of the SRB in determining surface rights awards and risk creating "an administrative nightmare." ${ }^{109}$ The Court noted that the purpose of the SRB is to apply an "expeditious yet fair method of establishing appropriate compensation for, inter alia, Loss of Use. The emphasis is on procedurally expeditious resolution of conflicts."110

$\begin{array}{ll}104 & \text { Ibid; Husky Oil, supra note } 102 \text { at para } 2 . \\ 105 & \text { Husky Oil, ibid at para 5. } \\ 106 & \text { Ibid at para 12. } \\ 107 & \text { Ibid at para 17. } \\ 108 & \text { Ibid at para 66. } \\ 109 & \text { Ibid at para 65. } \\ 110 & \text { Ibid at para 64. }\end{array}$


In upholding the intent of the Act and providing an efficient manner in calculating and awarding surface access costs, the SRB has chosen a path which keeps control of the expediency factor in determining "loss of use" in this and previous cases. ${ }^{111}$

In concluding that the SRB's decision was reasonable, the Court stated that the "SRB is entitled to consider what it would accept to prove actual costs and whether doing so might open up a plethora of inquiries which would lead to protracted and inefficient SRB proceedings."112

\section{COMMENTARY}

This decision shows that the court will grant deference to reasonable decisions of a regulatory tribunal. In this case, the Court was satisfied that the evidence provided by Scriber was sufficient to show the realities involved in the farming practices in the region and to allow the SRB to make a reasonable decision based on all the factors presented. Furthermore, this case shows the overall importance that the court places on ensuring that the regulatory process is not only fair, but efficient.

\section{INTER PIPELINE FUnd \\ V. AlbERTA (ENERGY RESOURCES CONSERVATION BOARD) ${ }^{113}$}

\section{BACKGROUND}

This case deals with the adequacy of reasons in a decision provided by the ERCB and with the concept of procedural fairness in ERCB hearings.

\section{FACTS}

Taylor Processing Inc. (Taylor) sought the ERCB's approval for a co-streaming project at its Harmattan plant. The project was intended to alter the existing gas processing facility and then divert natural gas to it from a common stream of gas owned by various parties, remove certain natural gas liquids (NGLs) from the gas and return the residue gas to the common stream downstream of a straddle plant owned by Inter Pipeline Fund (Inter Pipeline) in Cochrane. ${ }^{114}$ BP Canada Energy Company and BP Canada Energy Resources Company (collectively BP) purchased NGLs from Inter Pipeline's Cochrane plant, own a pipeline that transports NGLs from Cochrane to Edmonton, and own straddle plant capacity at Empress. ${ }^{115}$

Inter Pipeline and BP objected to Taylor's application and the ERCB held a hearing on the matter. Among the procedural steps followed were:

(1) Inter Pipeline's request for an information request process (which was granted by the ERCB);

$\begin{array}{ll}111 & \text { Ibid at para 63. } \\ 112 & \text { Ibid at para 69. } \\ 113 & \text { 2012 ABCA } 208533 \text { AR } 331 . \\ 114 & \text { Ibid at para } 3 . \\ 115 & \text { Ibid at para } 4 .\end{array}$


(2) BP's request for an adjournment to retain new counsel (which was denied by the ERCB); and

(3) BP's application for further and better responses to the information request (which was denied in part by the ERCB). ${ }^{116}$

Taylor's application initially relied on a gas supply forecast prepared in July 2009 by Ziff Energy Group (the Ziff Forecast), but Taylor later submitted a new forecast prepared by TransCanada Pipelines Limited (TCPL) and advised the ERCB that it would not be relying on the Ziff Forecast or calling any experts in respect of the Ziff Forecast. ${ }^{117}$

The ERCB ultimately approved Taylor's application on the basis that the project was in the public interest. In its decision, the ERCB stated:

The Board also notes that its assessment of the public interest with respect to the Applications requires considering the factors from the NGL Inquiry report. It also notes that these factors vary in significance, depending on the facts, circumstances, and issues surrounding a particular co-streaming or side-streaming application and that no single objective test of what constitutes the public interest can be formed. It is the Board's view that no single factor presents a barrier to the approval of a project that may be in the overall public interest. $^{118}$

\section{DECISION}

\section{a. Adequacy of Reasons}

Inter Pipeline's position was that the ERCB failed to explain its reasons for giving the same weight to the TCPL gas forecast as it did to the forecast provided by Inter Pipeline. The Court disagreed with Inter Pipeline's argument, finding that the ERCB's decision did not give the two forecasts the same weight, as the ERCB referred to the TCPL report being on the high end and the Inter Pipeline report being on the low end. ${ }^{119}$ The Court found that the ERCB, before making its decision, had sufficient evidence to support its conclusions, including a number of gas supply forecasts. ${ }^{120}$ The Court ruled that in regulatory matters, the weighing of evidence is a matter for the ERCB, not a reviewing Court. ${ }^{121}$ A court cannot conclude that reasons are inadequate simply because they may disagree with a tribunal's conclusion, based on evidence before it. ${ }^{122}$

\section{b. Procedural Fairness}

BP's main argument was that it was denied procedural fairness, and as a result, Taylor did not provide sufficient replies pursuant to the information request. In particular, BP complained of the fact that it did not have the opportunity to cross-examine the expert 
witness in respect of the Ziff Forecast, and its attempts at receiving information were further thwarted when Taylor elected not to rely on the Ziff Forecast and, instead, submitted the TCPL forecast. ${ }^{123}$

The Court noted that, as the Ziff Forecast was not relied on as evidence, obtaining further information in respect of the forecast through cross-examination would not have helped advance the process. ${ }^{124}$ With respect to Taylor's decision to rely on the TCPL forecast, BP had the opportunity to cross-examine Taylor's witness but chose not to. Further, BP elected to file its own evidence with respect to the gas supply matter. As a result, BP was not deprived of a reasonable opportunity to meet Taylor's case on the gas supply issue. ${ }^{125}$ The Court concluded its ruling on this issue by stating that: "BP was not deprived of its ability to be an informed advocate when the Board declined to order further information from Taylor on gas supply and extraction efficiency. BP was still entitled to put in its own evidence on these matters, to cross-examine, and to make final submissions."126

\section{COMMENTARY}

This case once again shows the level of deference that Courts will show to regulatory tribunals where the decisions fit within the reasonable spectrum. Further, it shows that if a party is to claim procedural unfairness, it must be certain that they have availed themselves of all rights and remedies at the regulatory tribunal stage. 